\title{
Enhancement of novel extracellular bacteriocin production by media optimization using LAB isolate from meat
}

\author{
Enas Nabil Danial ${ }^{1,4^{*}}$, Salha Hassan Mastour Al-Zahrani ${ }^{2}$, Zahra Al-Hassan Mohammad Al-Mahmoudi ${ }^{3}$ \\ ${ }^{1}$ Department of Biochemistry, Faculty of Science- Al Faisaliah, King abdulaziz University, Jeddah, Saudi Arabia. \\ ${ }^{2}$ Department of Biology, Faculty of Science- Al Faisaliah, King abdulaziz University, Jeddah, Saudi Arabia. \\ ${ }^{3}$ Department of Biology, Science faculty, Jeddah University, Jeddah, Saudi Arabia. \\ ${ }^{4}$ Department of natural and microbial products, National Research Center, Dokki, Cairo, Egypt.
}

\begin{tabular}{l} 
ARTICLE INFO \\
\hline Article history: \\
Received on: $29 / 10 / 2016$ \\
Revised on: 23/11/2016 \\
Accepted on: 05/12/2016 \\
Available online: 28/12/2016 \\
\hline Key words: \\
Bacteriocin, Lactic Acid \\
Bacteria, isolation, \\
production.
\end{tabular}

ABSTRACT
Bacteriocins from lactic acid bacteria have been widely studied in recent years; however, there is a little study
for explained their chemical compositions. This study was amid to isolate and identification Lactic Acid
Bacteria (LAB) from meat in Jeddah - Saudi Arabia on (MRS) medium. Forty isolates of LAB showed
antibacterial activities against indicator bacteria Gram negative bacteria $K$. pneumonia ATCC700603, E.coli
ATCC25422, P.aeruginosa, ATCC 27583 and Gram positive bacteria $S$.aureus ATCC 25923 . Also antibacterial
activities was screened by agar well diffusion method, results showed that ten out of 40 (25\%) of the tested
isolates have activities against all indicator bacteria. Isolates of LAB with the highest antimicrobial effect were
identified on the basis of its genetically sequencing. Results revealed that the M8 isolate have $96 \%$ identity with
Leuconostoc mesentroides and was the highest bacteriocin producer. So it has been selected for the current
investigation. The effect of different factors such as (inoculums concentrations, incubation temperature,
incubation period, pH and aeration) on the production was studied. The pointed to the best condition for the
bacteriocin production of highest amount of bacteriocin was incubation of static culture at $35^{\circ} \mathrm{C}$ for 24 hr. and
pH 6.2.

\section{INTRODUCTION}

Lactic acid bacteria (LAB) are the biological foundation for the production of a large number of fermented foods and dairy products (Lasagno et al., 2002 and Sarantinopoulos et al., 2002). It can be isolated naturally from several fermented foods such as fermented vegetable, fish, meat and milk (Salminen et al., 2004a). Lactic acid bacteria have been long decided as the natural flora in fermented food. Because LAB was believed to be safe; so, it has great potential to be used in bio preservation. The preserve effects of lactic acid bacteria are due to the production of large number of antimicrobial agents such as bacteriocin or related substances (Cocolin et al., 2007). Lactic acid bacteria produce a species of antibacterial agnate such as hydrogen peroxide, diacetyl, organic acids and bacteriocins or bactericidal

\footnotetext{
* Corresponding Author

Mailid:enas_mahdy@yahoo.com
}

proteins as byproducts of fermentation (Rajaram et al., 2010). Many bacteriocins are peptides which consists of 13 to 37 amino acids only (Joerger, 2003). They may inhabit bacteria belonging to the same species only, while others bacteriocins inhabit a broad range of Gram positive bacteria (Garneau et al., 2002).

Bacteriocins have senior potency for food preservation, as well as for human therapy as potential complement or replacements for currently used antibiotics (Ogunbanwo et al., 2003). In food preservation, the bacteriocins produced by LAB are commonly known as safe substances (GRAS property) they are not effected and non-toxic on the cells of eukaryotic, they become inactive by digestive proteases having little influence on the gut microbiota, (Gálvez et al., 2007).

The objective of this work is isolation and identification of LAB from meat collected from different districts in Jeddah city, KSA, for enhancement of bacteriocin Production 


\section{MATERIALS AND METHODS}

\section{Isolation of lactic acid bacteria Samples collection}

Forty samples of meat were collected from muscle of the domestic goat in different districts in Jeddah, Saudi Arabia. All the samples were used to isolate lactic acid bacteria using MRS agar medium. One gram of meat was transferred to $9 \mathrm{ml}$ sterile distilled water (under sterile conditions) and was shaken to get dilution of $10^{-1}$. Several dilutions were then made to obtain a proper dilution of $10^{-3}$

An aliquot of $0.1 \mathrm{ml}$ of each dilution was transferred over agar plates containing $15 \mathrm{ml}$ of sterile De Mann, Rogosa and Sharpe (MRS) media and incubated at $35^{\circ} \mathrm{C}$ for $24 \mathrm{~h}$.

\section{Screening of bacteriocin production by agar well diffusion} assay

Agar well diffusion procedure described by (Zhang et al., 2010), was used to determine the production of bacteriocin in the culture supernatant. Petri plates $(85 \mathrm{~mm} \times 15 \mathrm{~mm}$ ) were prepared by pouring $15 \mathrm{ml}$ of sterile MRS in each plate and the medium was left to solidify. About $0.1 \mathrm{ml}$ of an inoculum suspension of pathogens with concentration $4 \times 104 \mathrm{CFU} / \mathrm{ml}$ was poured and uniformly spread using sterile cotton swap was used to determine the bacteriocin production and efficiency to inhibit the bacterial growth. After inoculum absorption by agar, wells were made using sterile cork borers (diameter $5 \mathrm{~mm}$ ) and were filled with $100 \mu \mathrm{l}$ of the isolated stearin supernatant. Plates were left for $45 \mathrm{~min}$ in the refrigerator to allow proper diffusion of the supernatant in the medium. The plates were incubated at $35^{\circ} \mathrm{C}$ for $24 \mathrm{~h}$. Inhibition of bacterial growth was measured as inhibition zone diameters in $(\mathrm{mm})$. All experiments were carried out in triplicate. The LAB isolates showed the highest antimicrobial activity have been chosen to compare between their production efficiency of bacteriocin so that we can select the best of them for genetic identification.

Genetic identification of the chosen LAB producing the highest bacteriocin concentration

DNA isolation and PCR amplification

An overnight culture of the promised bacteria grown at $35^{\circ} \mathrm{C}$ was used for the DNA extraction using Promega kit. Amplification of $16 \mathrm{~S}$ rDNA region was carried out according to Sambrook et al. (1989) using polymerase chain reaction (PCR) and primers designed to amplify $1500 \mathrm{bp}$ fragment of the $16 \mathrm{~S}$ rDNA region. The domain bacteria-specific primer $27 \mathrm{~F}$ (forward primer) was:

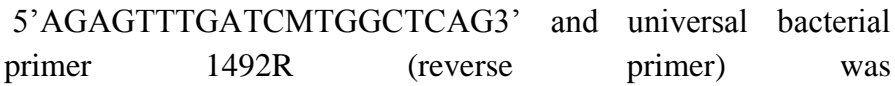
5'TACGGYTACCTTGTTACGACTT3' (Edwards et al., 1989). The PCR mixture consists of 30 picomoles of each primer, $10 \mathrm{ng}$ of chromosomal DNA, $200 \mu \mathrm{M}$ dNTPs and 2.5 Units of Taq polymerase in $50 \mu \mathrm{l}$ of polymerase buffer. The PCR was carried out for 30 cycles in $94{ }^{\circ} \mathrm{C}$ for $1 \mathrm{~min}, 55^{\circ} \mathrm{C}$ for $1 \mathrm{~min}$ and $72{ }^{\circ} \mathrm{C}$ for
2 minutes. After completion, a fraction of the PCR mixture was examined using agarose gel electrophoresis and the remnant was purified using QIAquick PCR purification reagents (Qiagen).

\section{DNA sequencing, phylogenic analysis and tree construction}

DNA sequences were obtained using $3130 \mathrm{X}$ DNA Sequencer (Genetic Analyzer, Applied Biosystems, Hitachi, Japan), BigDye Terminator Cycle Sequencing. The PCR product was sequenced using the same PCR primers. Automated DNA sequencing based on enzymatic chain terminator technique was done using 3130 X DNA Sequencer (Genetic Analyzer, Applied Biosystems, Hitachi, Japan).

The thermal cycling mixture was as follows: $8 \mu \mathrm{l}$ of Big dye terminator mix, $6 \mu \mathrm{l}$ of the sequencing primer $(10 \mathrm{pmol})$ and $6 \mu \mathrm{l}$ of the sample (PCR product) then the reaction was run in the thermal cycler. The cyclic reaction composed of $1 \mathrm{~min}$ at $95^{\circ} \mathrm{C}$, then 49 cycles of $30 \mathrm{sec}$ at $95{ }^{\circ} \mathrm{C}, 10 \mathrm{sec}$ at $52{ }^{\circ} \mathrm{C}$ and $4 \mathrm{~min}$ at $60{ }^{\circ} \mathrm{C}$. The products were purified using special column according to the instruction of the manufacturer. The elute were taken and (1:1) volume ratio of high dye formamide was added and run at 95 ${ }^{\circ} \mathrm{C}$ for $5 \mathrm{~min}$ for denaturation, then shock on ice. Afterward, the samples become ready for sequencing in 3130 X DNA sequencer and analysis.

Phylogenetic data were obtained by aligning the nucleotides of different $16 \mathrm{~S}$ RNA retrieved from BLAST algorithm (www.ncbi.nlm.nih.gov/BLAST), using the CLUSTAL $\mathrm{W}$ program version 1.8 with standard parameters. The classifier is trained on the new phylogenetically consistent higher-order bacterial taxonomy (Ribosomal Database Project, RDP Classifier) proposed by Wang et al. (2007), (http://rdp.cme.msu.edu/classifier/classifier.jsp). Phylogenetic and molecular evolutionary analyses were conducted using BioEdit version 7.0.4.01. A rooted phylogram was derived from the distance matrices using the neighbour-joining method through the TREEVIEW program. All analyses were performed on a bootstrapped data set containing 1000 replicates (generated by the program).

\section{Influence of growth conditions of the selected LAB on production of bacteriocin}

The culture condition experiments were performed in $250 \mathrm{ml}$ Erlenmeyer flasks containing $25 \mathrm{ml}$ of MRS broth medium and inoculated with slant from pre-culture of selected isolate. The flasks were incubated at $35^{\circ} \mathrm{C}$ for $24 \mathrm{~h}$, at the end of the incubation period; the cells were collected by centrifugation at $5000 \mathrm{rpm}$ for $20 \mathrm{~min}$ at $4^{\circ} \mathrm{C}$. Bacteriocin activity was assayed in the culture filtrate by the agar-well diffusion method as described before (Tagg and Given 1971).

\section{Effect of different concentrations of inoculum on growth and production of bacteriocin}

Different five concentrations of inoculums $(2.5 \mathrm{ml}, 5 \mathrm{ml}$, $7.5 \mathrm{ml}, 10 \mathrm{ml}$ and slant) were used for studying the effect of 
inoculums concentration on the growth and production of bacteriocin by the selected bacterial isolate.

\section{Effect of different incubation temperatures on growth and production of bacteriocin}

To study the effect of incubation temperature, the selected bacteria were grown in MRS broth medium at various incubation temperatures $\left(25,30,35,40\right.$ and $\left.45^{\circ} \mathrm{C}\right)$. Slant from preculture of selected isolate was suspended and inoculated in $250 \mathrm{ml}$ Erlenmeyer flasks of MRS broth medium.

\section{Effect of different incubation period on growth and production of bacteriocin}

To study the effect of incubation period, the tested organisms were grown in MRS broth medium at various incubation period $\left(24,48\right.$ and $72 \mathrm{~h}$ ), then incubation at $35^{\circ} \mathrm{C}$, slant from pre-culture of the selected bacterial isolate was suspended and inoculated in $250 \mathrm{ml}$ Erlenmeyer flasks of MRS broth medium.

\section{Effect of pH on growth and production of bacteriocin}

The effect of initial medium $\mathrm{pH}$ on growth and production of bacteriocin of selected isolates was tested. The MRS broth medium was prepared in $250 \mathrm{ml}$ Erlenmeyer flasks at different $\mathrm{pH}$ as following 4.2, 5.2, 6.2, 7.2, 8.2 and 9.2 with $6 \mathrm{M}$ $\mathrm{HCl}$ or $6 \mathrm{M} \mathrm{NaOH}$ and then autoclaved. Each flask were inoculated with inoculums of selected strains and incubated at 35 ${ }^{\circ} \mathrm{C}$ for $24 \mathrm{~h}$, without agitation. After changing the culture of $\mathrm{pH}$, the bacterial growth and the production of bacteriocin were measured.

\section{Effect of aeration on growth and production of bacteriocin}

The effect of aeration on antimicrobial activity was examined using $250 \mathrm{ml}$ Erlenmeyer flasks containing MRS broth medium, and inoculated with slant from pre culture of the selected $\mathrm{LAB}$ bacterial isolate. After that, the flasks were incubated at $35^{\circ} \mathrm{C}$ for $24 \mathrm{~h}$ with agitation at different agitation speed $(0,100,150$, $200,250 \mathrm{rpm})$. After $24 \mathrm{~h}$ of incubation the growth and the production of bacteriocin were measured as described before.

\section{Effect of media volume on growth and production of bacteriocin}

The effect of aeration on production of bacteriocin was examined using $250 \mathrm{ml}$ Erlenmeyer flasks containing MRS broth medium inoculated with $2 \mathrm{ml}$ of Dist. $\mathrm{H}_{2} \mathrm{O}$ with slant from preculture of the selected bacterial isolate. The cultures were incubated at $35^{\circ} \mathrm{C}$ for $24 \mathrm{~h}$ without agitation static $(0 \mathrm{rpm})$. At the end of growth period the growth of inoculated bacteria and antimicrobial activity were measured as described before

\section{RESULTS AND DISCUSSION}

In the present work eight bacterial isolates were obtained, from the examined forty meat samples and were given the symbol
M (M1, M2, M3, M4, M5, M6, M7 and M8). LAB commonly inhabits the muscle of the domestic goat. This may be due to the chemical composition of the muscle, encouraging the growth of the lactic acid producing bacteria. It was in agreement with Olaoye and Onilude (2008), who isolated LAB strains from cow's meat. Also,Olarte et al (2000) mentioned that Lactobacillus plantarum was isolated from Cameros cheese produced from goat's milk and this bacterium decreased the number of Enterobacteria and fecal coliforms in the final cheese product

\section{Isolation of LAB bacteria}

The isolated LAB cultural characteristics were Gram positive, ranged between round, smooth, drop-like, raised and flat. The Color varied between white, yellowish and bright white. Table (1) shows the efficiency of the eight bacterial isolates in production of bacteriocin and inhibition of pathogenic bacteria.

Table 1: Degree of inhibition of different indicator bacteria by bacteriocin produced by different LAB isolates obtained from meat.

\section{Indicator microorganisms}

\begin{tabular}{|c|c|c|c|}
\hline 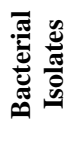 & 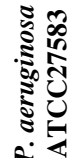 & 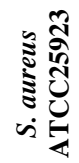 & 芯 \\
\hline
\end{tabular}

\begin{tabular}{lcccc}
\hline M1 & - & - & - & - \\
M2 & +++ & +++ & +++ & +++ \\
M3 & ++ & + & ++ & + \\
M4 & + & + & + & + \\
M5 & +++ & +++ & +++ & +++ \\
M6 & ++ & + & + & + \\
M7 & - & - & - & - \\
M8 & +++ & +++ & +++ & +++ \\
\hline
\end{tabular}

* Very high production (+++), moderate (++), few (+) and (-) no inhibition zone.

The higher antimicrobial activity of the studied $L A B$ was against S.aureus ATCC25923 and E.coli ATCC25422 followed by P.aeruginosa ATCC27583 and K.pneumonia ATCC700603. It might due to specific medium MRS, which is one of the best media suitable for the isolation of LAB as reported earlier by Ghoddusi (2002). Other studies deserted that MRS medium is a best medium for bacteriocin production and growth of cell than other conventional media (Daba et al., 1991).

Table 2: Estimation of bacteriocin production by LAB isolates using agar well diffusion assay against different indicator bacteria Indicator microorganisms

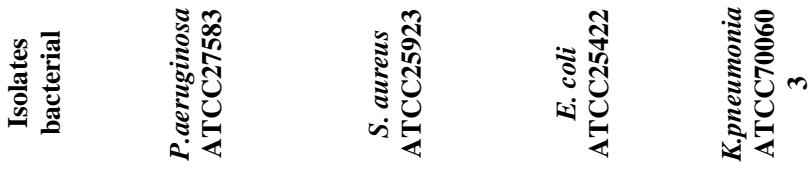

\begin{tabular}{lllll} 
& \multicolumn{4}{c}{ Mean diameter of inhibition zones $(\mathbf{m m})$} \\
\cline { 2 - 5 } M2 & $19.66 \pm 0.57$ & $18.66 \pm 0.57$ & $20.66 \pm 0.57$ & $20.33 \pm 0.57$ \\
M5 & $21.33 \pm 0.57$ & $20.33 \pm 0.57$ & $19.33 \pm 0.57$ & $20 \pm 1$ \\
M8 & $22.66 \pm 0.57$ & $22.00 \pm 0.57$ & $22.66 \pm 0.57$ & $23.66 \pm 0.57$ \\
\hline
\end{tabular}




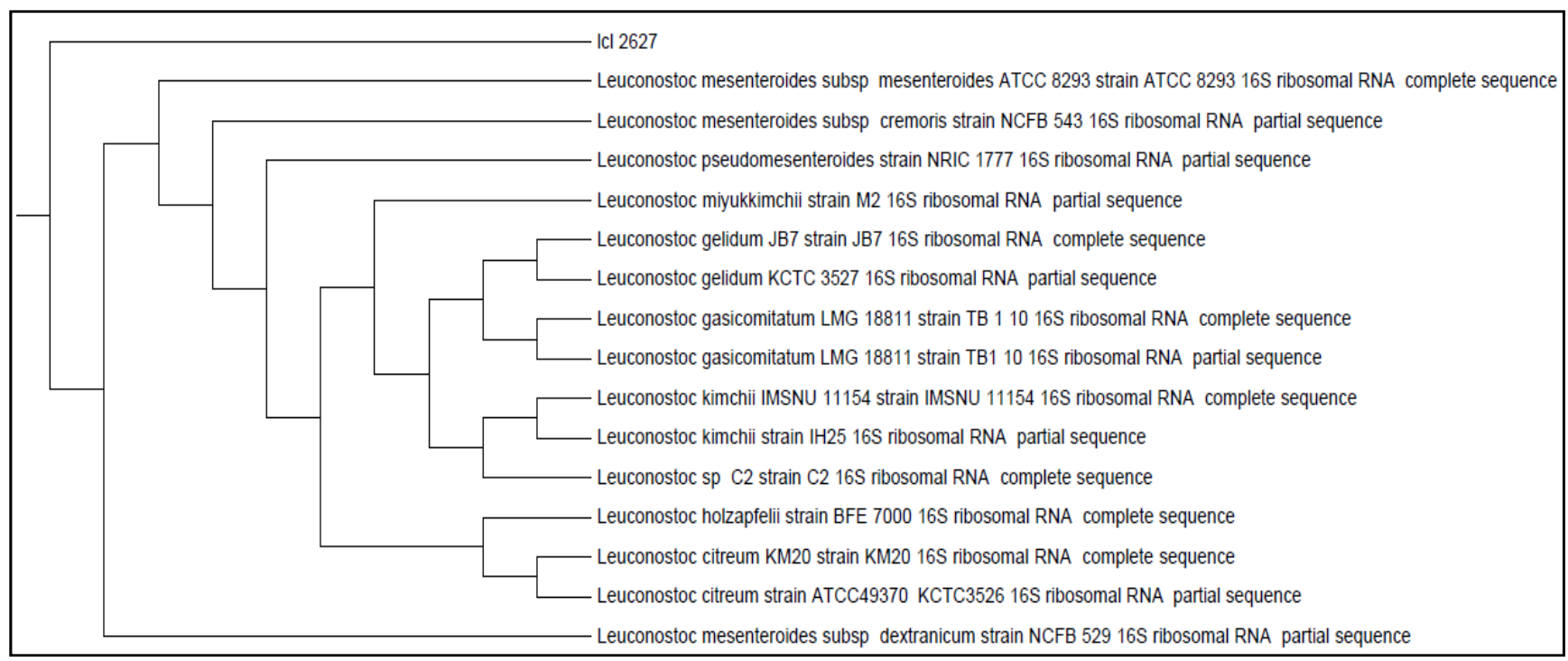

Fig. 1: Phylogenetic tree based on 16S rRNA sequence comparisons of Leuconostoc mesenteroides subsp. mesenteroides ATCC 8293 (M8).

The current study clarified that M8 showed the highest antibacterial or antipathogenic effect. This may be explained in the light of organic acid and bacterocin production that can inhibit growth of indicator bacteria. (Malago and Koninkx, 2011). Some LAB species possess a high ability to inhibit Staphylococcus species growth and proliferation via competition on their nutritional requirements (Cadieux et al., 2002 \& Al-Zahrani and Al-Zahrani, 2006). Wang et al. (2012) showed that several Lactobacillus species, such as L. crispatus and L. jensenii demonstrated the ability to inhibit $S$. aureus growth in vitro.

Table (2) showed that out of the best three chosen bacterial isolates, M8 had the highest bacteriocin production. So, M8 was the best chosen isolate for the following chemical study and genetic identification.

The current isolated species through this study were confirmed to exhibit a very high homology with E. durans group $(96 \%)$ in its $16 \mathrm{~S}$ rRNA nucleotide sequence. According to the obtained results, isolates $\mathrm{C} 16$ was identified as Enterococcus durans strain 98D. Finally, the $16 \mathrm{~S}$ rRNA nucleotide sequence of the M8 was compared with those of conventional coocii strains. As a result, the cocci species isolated through this study were confirmed to exhibit a very high homology with L.mesenteroides group (95\%) in its 16S rRNA nucleotide sequence. According to the obtained results, isolates M8 was identified as Leuconostoc mesenteroides subsp. mesenteroides ATCC 8293. These results were agreement with (Al-Zahrani and Al-Zahrani, 2006) who found that, all LAB isolates from different samples of goat's milk and camel's milk were coccal only. Also, Assefa et al. (2008) and Cullimore (2000) respectively, isolated some LAB from different habitats using MRS agar medium and were either cocci or bacilli and belonged to Gram-positive bacteria. Antimicrobial agent is a common term used to, point to any compound which contain antibiotics, disinfectants,sanitizer, food antimicrobial agents and other substances that acts against microorganisms. Lactic acid bacteria as antimicrobial agent are widely distributed in the nature.

\section{Effect of different inoculums size on growth and production of bacteriocin}

The results of different concentrations of the inoculums affected both growth and production of bacterocin. All preparations with different conditions were propagated under the same conditions, and assayed for production of bacteriocin as described before. The data in figure (2) show that, the mean diameter of inhibition zone against P.aeruginosa ATCC27583 was ranged from 24.66 to $18.66 \mathrm{~mm}$.

The mean diameter of inhibition zone was $24.66 \mathrm{~mm}$ by slant inoculums then $23 \mathrm{~mm}$ by $10 \%$ inoculums, while inoculums $2.5 \%$ have the lowest the production of bacteriocin, the mean diameter of inhibition zone was $18.66 \mathrm{~mm}$.Using (7.5 and 5\%) of the inoculums concentrations of revealed that the level of activities ranged between 21.66 and $20.33 \mathrm{~mm}$, respectively while the mean diameter of inhibition zone against S.aureus ATCC25923 ranged from 24 to $17.66 \mathrm{~mm}$. Using slant inoculum after incubation revealed the highest production of bacteriocin, the mean diameter of inhibition zone was $24 \mathrm{~mm}$, while inoculums $2.5 \%$ have the lowest inhibition zone $(17.66 \mathrm{~mm})$.

Akinkugbe et al. (2013) reported that at $0.5 \mathrm{~mL}$ inoculum concentration, protease production of $L$. lactis decreased after starting off with a high value at $\mathrm{pH} 4.0$. At $1.0 \mathrm{~mL}$ inoculum concentration, it reached its peak at $\mathrm{pH} 5.0$ and maintained it. At an inoculum concentration of $1.5 \mathrm{~mL}$, it gradually rose to peak respectively at $\mathrm{pH} 5.0$ and 5.5 to both become stable afterwards. With $2.0 \mathrm{~mL}$ concentration, protease production increased gradually, till a peak at 5.5 (peak height) was attained. 
Your figures contain lot of data so that may be confusing. I think it is better to put your data in tables because there are differences in colors of the same type of bacteria in different figures and this is confusing to readers and reviewers. CDW mentioned inside the figure is not identified inside text.
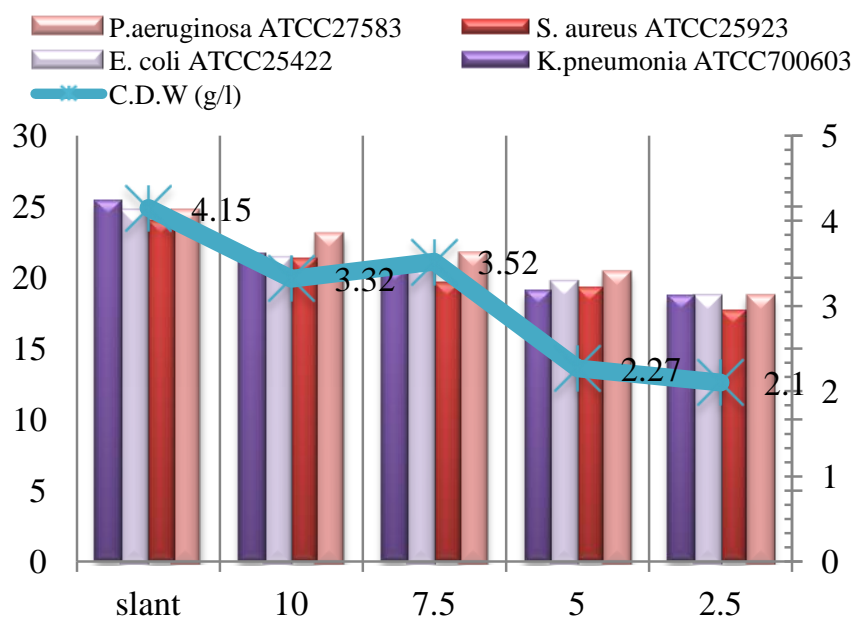

Different size of inoculum

Fig. 2: Effect of different inoculums size on growth and production of bacteriocin It is recommended to unify the colors of the presented bacteria in all figures

The lowest inhibition zone was $18.66 \mathrm{~mm}$ by $2.5 \%$ inoculum. The inhibition zone diameter against K.pneumonia ATCC700603 ranged from 25.33 to $18.66 \mathrm{~mm}$, The most activity was $(25.33 \mathrm{~mm})$ by slant inoculum, while $2.5 \%$ of the inoculum revealed to the lowest production of bacteriocin the diameter of inhibition zone was $18.66 \mathrm{~mm}$ by $2.5 \%$ inoculums.

Finally, $2.5 \%$ inoculums recorded lower growth $2.10 \mathrm{~g} / \mathrm{l}$ and the slant inoculum recorded highest growth $4.15 \mathrm{~g} / \mathrm{l}$. The highest inhibition zone and highest growth of selected isolate were by using the slant as inoculums. On the other hand, $2.5 \%$ inoculum recorded lower growth and Inhibition zone.

\section{Effect of incubation temperature on growth and production of bacteriocin}

Effect of different incubation temperature the selected bacterial isolate (M8) showed the maximum production of bacteriocin at $35^{\circ} \mathrm{C}$ and the inhibition zone diameter ranged from 20 to $24 \mathrm{~mm}$, the highest inhibition zone was $23.66 \mathrm{~mm}$ against K.pneumonia ATCC 700603 at $35^{\circ} \mathrm{C}$ and the lowest was $20.33 \mathrm{~mm}$ against K.pneumonia ATCC700603. At $40,45^{\circ} \mathrm{C}$ the bacteria showed negative results.

Finally, $25^{\circ} \mathrm{C}$ recorded lower growth $1.09 \mathrm{~g} / 1$ and $35^{\circ} \mathrm{C}$ recorded the highest growth $2.58 \mathrm{~g} / \mathrm{l}$. The highest inhibition zone and highest growth of the selected isolate by using the $35^{\circ} \mathrm{C}$ temperature. On the other hand, 40 and $45^{\circ} \mathrm{C}$ recorded no growth and no Inhibition zone. So the optimum temperature for growth and the highest inhibition zone was found to be $35^{\circ} \mathrm{C}$ (Figure 3). A lowering in production of bacteriocin at $25^{\circ} \mathrm{C}$ and disappeared at $40,45^{\circ} \mathrm{C}$ for 24 hours was observed when compared to incubation at $35^{\circ} \mathrm{C}$. The effect of temperature on cell growth and bacteriocin production has been previously reported by Matsusaki et al. (1996). Also, Leroy and De Vuyst (2002) studied the production of bacteriocin by Enterococcus faecium RZS C5 under different temperatures and obtained similar results with less bacteriocin production below $35^{\circ} \mathrm{C}$; and this may be due to cellular environment regulation and growth related processes.

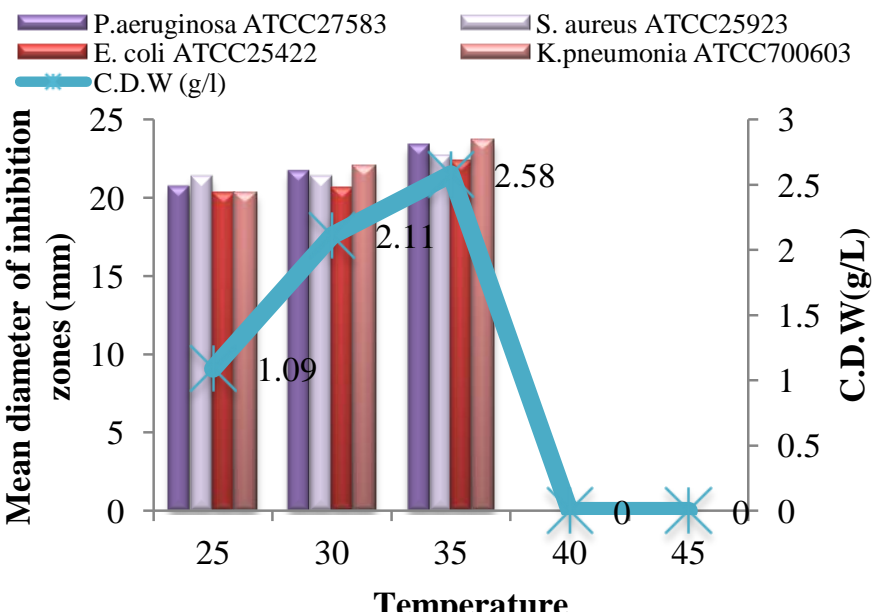

Temperature

Fig. 3: Effect of incubation temperature on growth and production of bacteriocin

\section{Effect of incubation period on growth and production of bacterocin}

The maximum production of bacterocin was observed after $24 \mathrm{~h}$ incubation. Increasing the incubation period more than $24 \mathrm{~h}$, the production of bacterocin was decreased (Figure 4).

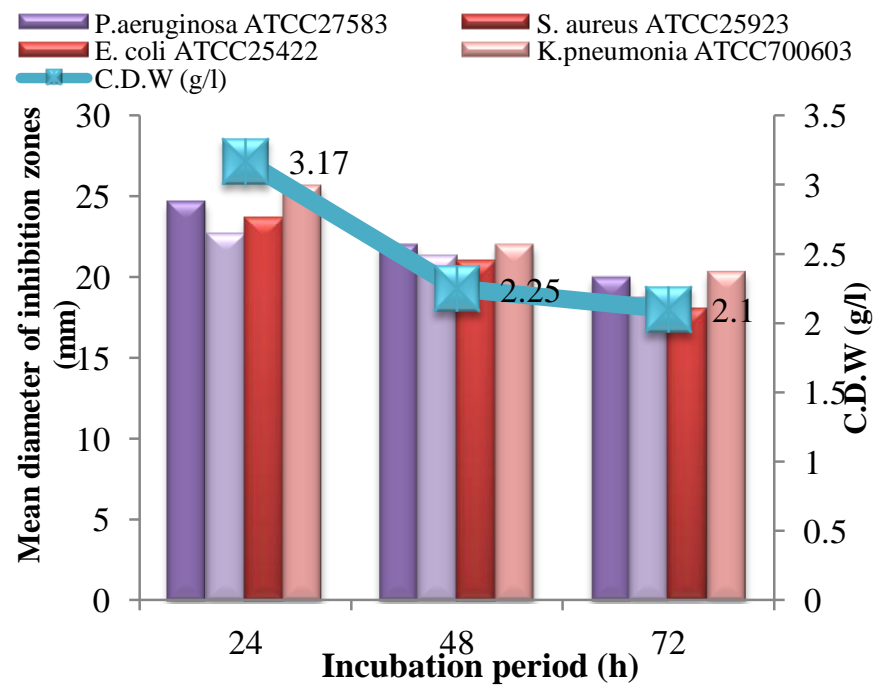

Fig. 4: Effect of incubation period on growth and production of bacteriocin

The highest clear zone was recorded $(25.66 \mathrm{~mm})$ against K.pneumonia ATCC700603 follow (24.66mm) against P.aeruginosa ATCC27583 after $24 \mathrm{~h}$ incubation period. The lowest clear zone was recorded after $72 \mathrm{~h}$ incubation period 
inhibition zone reach (18mm) against E.coli. After $48 \mathrm{~h}$ incubation period the inhibition zone ranged between $22-21 \mathrm{~mm}$. These results were similar to those reported by Campos et al. (2006), it was seen in this study that an incubation period of 24-48 hours give maximum bacteriocin production. On the other hand, the yield of bacteriocin was low in cultures incubated for more than 30 hours similar observations have been made previously. This decrease could be due to the effect of extra cellular endogenous proteinase evolved during prolonged incubation (Piard et al., 1990). Usually, bacteriocin is optimally secreted or produced in the culture broth during the stationary phase of growth. For Pediococcus acidilactici, culturing at $40{ }^{\circ} \mathrm{C}$ promotes earlier optimum bacteriocin production of around 10-12 hours but Sagpao et al., (2007) reported that, at $37^{\circ} \mathrm{C}$, bacteriocin production is form after 14-16 hours

\section{Effect of $\mathrm{pH}$ on growth and production of bacteriocin}

The selected strain (M8) was inoculated in MRS broth medium at $35^{\circ} \mathrm{C}$ for $24 \mathrm{~h}$ at different $\mathrm{pH}(4.2,5.2,6.2,7.2,8.2$ and 9.2). The microbial growth and production of bacterocin they were estimated. The results were summarized in (Figure 5) showed that the maximum of production of bacterocin and bacterial growth was found at $\mathrm{pH} 6.2$

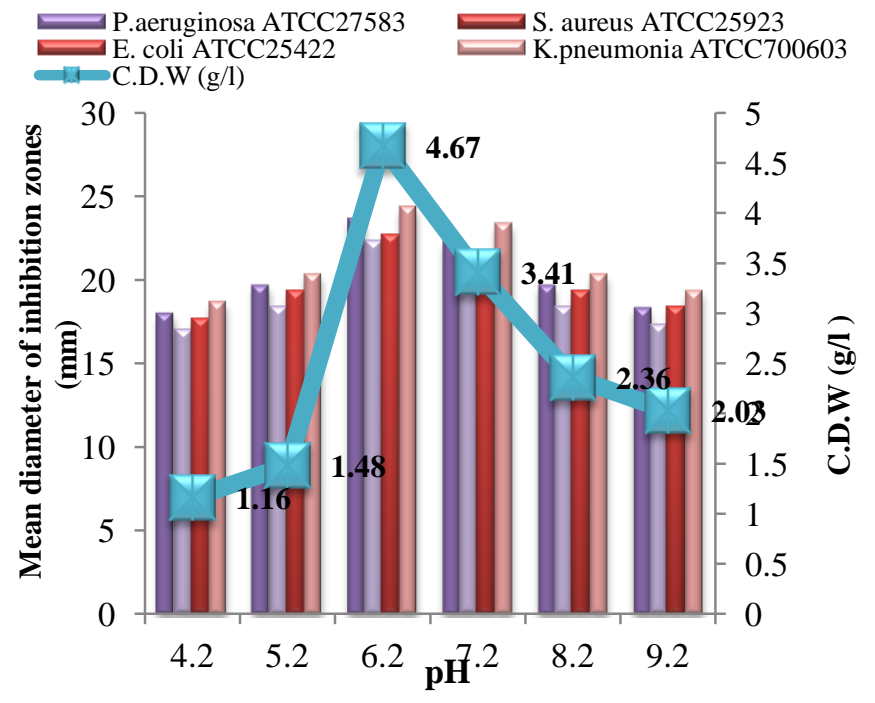

Fig. 5: Effect of $\mathrm{pH}$ on growth and production of bacteriocin

The results showed that the production of bacterocin ranged between 24.33 to $17.33 \mathrm{~mm}$. The highest mean diameter of inhibition zones were 24.33 against K.pneumonia ATCC700603 at $\mathrm{pH}$ 6.2. On the other hand, the lowest diameter of inhibition zone was $17.33 \mathrm{~mm}$ against S.aureus ATCC25923. Finally, $\mathrm{pH}(6.2)$ was the optimum for production of bacteriocin and bacterial growth (reach $4.67 \mathrm{~g} / \mathrm{l}$ ). Bacteriocin is one of the antibacterial agents produced by $\mathrm{LAB}$, and its activity is high at $\mathrm{pH}$ values ranging from 5.8 to 6.5 (Nilsen et al., 1998). Luo et al. (2011) reported that the effect of $\mathrm{pH}$ on produced antibacterial agents is not strong in three out of five supernatant strains, showing inhibition in $\mathrm{pH}$ range of 3.0 to 9.0 .

\section{Effect of aeration on growth and production of bacteriocin}

The results mentioned in Figure (6) showed that the maximum of production of bacteriocin and bacterial growth was found in shacked culture at rpm (static). The results showed that the production of bacteriocin ranged between 24.33 to $18.33 \mathrm{~mm}$. The mean diameter of inhibition zones against P.aeruginosa ATCC27583 were ranged from 23.66 to $19 \mathrm{~mm}$. The most activity was by zero speed of shaking reached $23.66 \mathrm{~mm}$, while 250 speed of shaking have the lowest production of bacteriocin the diameter of inhibition zone was $19 \mathrm{~mm}$. On the other hand, the mean diameter of inhibition zones against S.aureus ATCC25923 was ranged from 22.33 to $18.33 \mathrm{~mm}$. The most activity was by zero speed of shaking reached $(22.33 \mathrm{~mm})$, while 250 speed of shaking have the lowest mean diameter of inhibition zone was $18.33 \mathrm{~mm}$. The mean diameter of inhibition zone against E.coli ATCC25422 were ranged from 22.66 to $19.33 \mathrm{~mm}$, the most activity was by zero speed of shaking reached $(22.66 \mathrm{~mm})$, while 250 speed of shaking have the lowest production of bacteriocin, the diameter of inhibition zone was $19.33 \mathrm{~mm}$. The inhibition zone diameter against K.pneumonia ATCC700603 were ranged from 24.33 to $20.33 \mathrm{~mm}$, the most activity was by zero speed of shaking reached $(24.33 \mathrm{~mm})$, while 250 speed of shaking have the lowest production of bacterocin the diameter of inhibition zone was (19.33mm).

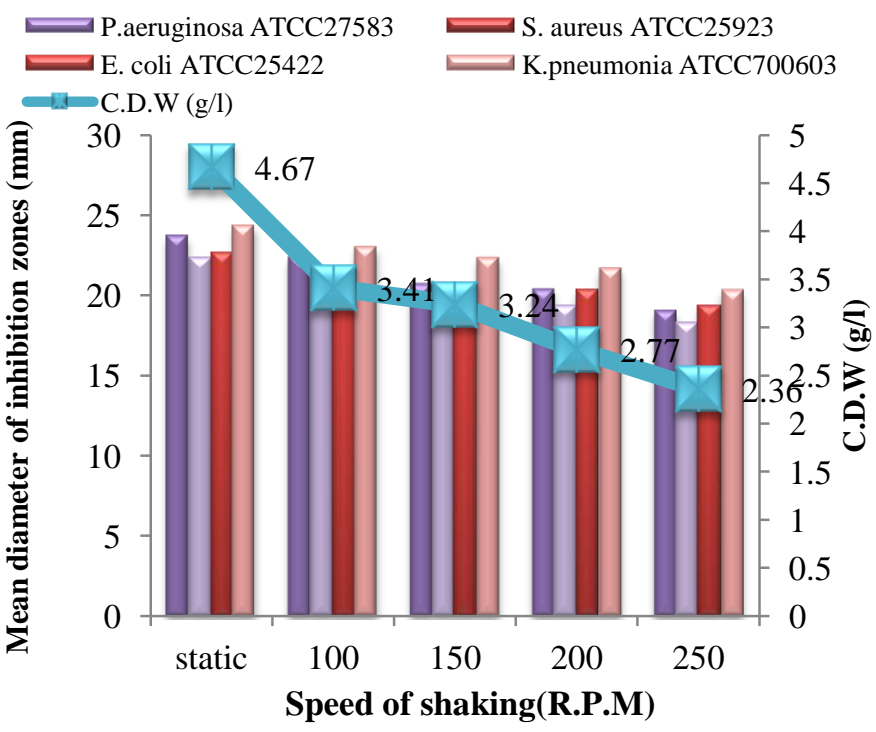

Fig. 6: Effect of aeration on growth and production of bacteriocin

Zero speed of shaking was the optimum incubation period for bacterial growth reach $4.67 \mathrm{~g} / \mathrm{l}$ while bacterial growth reaches $2.36 \mathrm{~g} / 1$ the lowest growth at $250 \mathrm{rpm}$. The results show that, bacteriocin was active under limited or reduced oxygen in the medium as indicated by Verluyten et al. (2003). Haoever, this 
results were un agreement with (De Vuyst and Vandamme, 1994) who found the suitable conditions for nisin production are not typical (no aeration and moderate shaking) or those proposed much earlier by (Hirsch, 1951), who suggested to apply strict anaerobiosis. These discrepancies can be ascribed to variations amongst different strains. Agitation speed and aeration also affected on bacteriocin production, it is noted that, the increases of these parameters often result in decrease of bacteriocin activity, perhaps because of chemical degradation and effects on gene expression (Parente and Ricciardi, 1999).

\section{Effect of volume of medium on growth and production of bacteriocin}

The selected strain (M8) was inoculated in different volume of MRS broth medium $(25,50,75$ and $100 \mathrm{ml})$, the $\mathrm{pH}$ adjusted at 6.2 at $35^{\circ} \mathrm{C}$ for $24 \mathrm{~h}$ without agitation (zero rpm). The microbial growth and production of bacteriocin they were estimated. The results were summarized in (Figure 7) they showed that the maximum of production of bacterocin and bacterial growth was found in $25 \mathrm{ml}$ of MRS broth medium. The results were showed the production of bacteriocin ranged between 24.33 to $18.66 \mathrm{~mm}$, the maximum of production of bacteriocin $24.33 \mathrm{~mm}$ against K.pneumonia ATCC700603 and the maximum bacterial growth $3.18 \mathrm{~g} / \mathrm{l}$ was found in $25 \mathrm{ml}$, while the lowest of production of bacteriocin $18.66 \mathrm{~mm}$ against $S$. aureus ATCC25923 in 100ml, the lowest bacterial growth $2.18 \mathrm{~g} / \mathrm{l}$ was found in $100 \mathrm{ml}$.

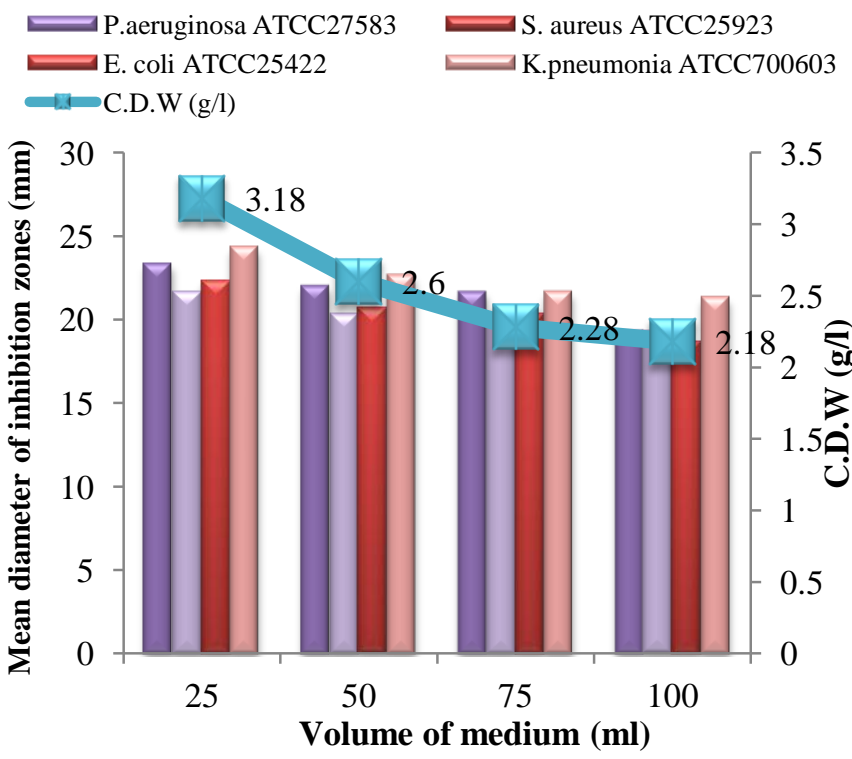

Figure 7: Effect of volume of medium on growth and production of bacteriocin

Generally, bacteriocin production is highly dependent on cell or biomass growth. LAB are microaerophilic and most are either mesophilic or slightly thermophilic. The following conditions are applicable to their production: $\mathrm{pH}=5.5$ to 6.0 ; temperature $=35$ to $40{ }^{\circ} \mathrm{C}$; agitation speed $=0 \mathrm{rpm}$. Usually, bacteriocin is optimally produced or secreted in the culture broth during the early stationary phase of growth. For Pediococcus acidilactici, culturing at $40{ }^{\circ} \mathrm{C}$ promotes earlier optimum bacteriocin production of around 10-12 hours at $37{ }^{\circ} \mathrm{C}$. Agitation speed and aeration also affected on bacteriocin production, it is noted that, the increases of these parameters often result in decrease of bacteriocin activity, perhaps because of chemical degradation and effects on gene expression (Parente and Ricciardi, 1999).

\section{Financial support and sponsorship: Nil.}

Conflict of Interests: There are no conflicts of interest.

\section{REFERENCES}

Al-Zahrani S, Al-Zahrani F. Production of bacteriocin by four lactic acid bacteria isolated from raw milk on organic waste, W App Sci J, 2006; 1 (20):135-143.

Anastasiadou S, Papagianni M, Filiousis G, Ambrosiadis I, Koidis P. Pediocin SA-1, an antimicrobial peptide from Pediococcus acidilactici NRRL B5627: Production conditions, purification and characterization, Bioresource Tech J, 2008; 99 (13): 5384-5390.

Assefa E, Beyene F, Santhanam A. Isolation and characterization of inhibitory substance producing lactic acid bacteria from Ergo, Ethiopian traditional fermented milk, Livestock Research for Rural Development, 2008; 20 (3):1-6.

Aukrust T, Blom H. Transformation of Lactobacillus strains used in meat and vegetable fermentations, Food Research International 1992; 25: 253-261.

Bredholt S, Nesbakken T, Holck A. Protective cultures inhibit growth of Listeria monocytogenes and Escherichia coli 0157:H7 in cooked, sliced vacuum- and gaspackaged meat, Int J Food Micr, 1999; 53: 43-52.

Cadieux P, Burton J, Gardiner G, Braunstein I, Bruce AW, Kang CY, Reid G. Lactobacillus strains and vaginal ecology. JAMA, 2002; 287: 1940-1941.

Campos CA, Rodriguez O, Calo-Mata P, Prado M, BarrosVelazque J. Preliminary characterization of bacteriocins from Lactococcus lactis, Enteroccus faecium and Enterococus mundtii strains isolated from Turbot (Psetta Maxima), Food Research Int, 2006; 39(3): 356-364.

Cocolin L R, Foschino G, Fortina MG. Description of the bacteriocins produced by two strains of Enterococcus faecium isolated from Italian goat milk, Int J Food Micr, 2007; 31: 753-758.

Cullimore DR 2000, Practical Atlas for Bacterial identification, Lewis Publishers, London, 13-102.

Daba H, Pandian S, Gosselin JF, Simard RE, Huang J, Lacroix C. Detection and activity of bacteriocin produced by Leuconostoc mesenteroides, App Environmental Micro, 1991; 57: 3450-3455.

De Vuyst L, Vandamme EJ. Nisin, Antibiotic Produced by Lactococcus lactis subsp. Lactis Properties Biosynthesis Fermentation and Applications, Bacteriocins of Lactic Acid Bacteria, Microbiology Genetics and Applications, 1994; 151-221

Edwards U, Rogall T, Blocker H, Emde M, Bottger EC. Isolation and direct complete nucleotide determination of entire genes. Nucleic Acids Res 1989; 17: 7843-785.

Gálvez A, Abriouel H, Lpez RL, Omar NB. Bacteriocin-based strategies for food biopreservation, Int J Food Micr, 2007; 120: 51-70.

Garneau S, Martin NI, Vederas JC. Two-peptide bacteriocins produced by lactic acid bacteria, Int J Bioch, 2002; 84: 577-592.

Ghoddusi HB. A comparative study on suitability of culture media for yogurt starter culture, J Agr Sci Tech, 2002; 16(1):153-160.

Gilliland S, Speck M. Antagonistic action of Lactobacillus acidophilus toward intestinal and foodborne pathogens in associative cultures, J Food Protection, 1977; 40: 820-823. 
Hirsch, A. Growth and nisin production of a strain of Streptococcus lactis, J general micr, 1951; 5: 20-21.

Joerger RD. Alternatives to Antibiotics: Bacteriocins, Antimicrobial Peptides and Bacteriophages, Poultry Sci, 2003; 82:640647.

Klaenhammer TR. Bacteriocins of lactic acid bacteria, International Journal of Biochemistry and Molecular Biology, 1988; 70: 337-349.

Lasagno M, Beoletto V, Sesma F, Raya R, Font De Valdez G, Eraso A. Selection of bacteriocin producer strains of lactic acid bacteria from a dairy environment, Revista Argentina Micr, 2002; 25: 37-44

Leroy $\mathrm{F}$, De Vuyst L. Bacteriocin production by E. faecium RZSC5 is cell density limited and occurs in the very early growth phase, Int J Food Micr, 2002; 72(102): 155-164

Luo F, Feng S, Sun Q, Xiang W L, Zhao J, Zhang J, Yang, ZR. Screening for bacteriocinproducing lactic acid bacteria from Kurut, a tradiational naturally fermented yak milk from Qinghai-Tibet plateau, Food Control J, 2011; 22: (1) 50-53.

Matsusaki H, Endo N, Sonomoto K , Ishizaki A. Lantibiotic nisin $\mathrm{Z}$ fermentative production by Lactococcus lactis IO-1, relationship between production of the lantibiotic and lactate and cell growth, Journal of Micr Biot, 1996; 45: 36-40.

Nilsen T, Nes IF, Holo H. An exported inducer peptide regulates bacteriocin production in Enterococcus faecium CTC492, J Bact, 1998; 180: 1848-1854

Ogunbanwo ST, Sanni AI, Onilude AA. Characterization of bacteriocin produced by Lactobacillus plantarum F1 and Lactobacillus brevis OGI, Afr J Biot, 2003; 2(7): 219-227.

Olaoye OA, Onilude AA. Identification of Pediococcus spp. from beef and evaluation of their lactic acid production in varying concentrations of different carbon sources, Adv Natural App Sci, 2008; 2(3): 197-207.

Olarte CS, Sanz EG, Fandas, Torre P. The effect of a commercial starter culture addition on the ripening of an artisanal Goat's cheese (Cameros Cheese), J App Micr, 2000; 88(3): 421-429.

Parente E, Ricciardi A. Production, recovery and purification of bacteriocins from lactic acid bacteria. App Micr Biot, 1999; 52: 628-638.

Piard JC, Delorme F, Giraffa G, Commissaire J, Desmazeaud M. Evidence for a bacteriocin produced by Lactococcus lactis CNRZ 481, Netherlands milk dairy j, 1990; 44:143-158
Rajaram G, Manivasagan, P, Thilagavathi B, Saravanakumar A. Purification and Characterization of a Bacteriocin Produced by Lactobacillus lactis Isolated from Marine Environment, Advance J Food Sci Tech, 2010; 2: 138-144.

Salminen S, Gobrbach S, Lee, YK, Benno Y. 2004 Human Studies on Probiotics: What is Scientifically Proven Today, In Lactic Acid Bacteria, Microbiology and functional aspects, Edited by S. Salminen, A.v. Wright and A. Ouwehand, Marcel Dekker, New Yourk, Inc. 515-530.

Sambrook J, Fritsch EF, Maniatis T. 1989. Molecular cloning A. Laboratory Manual. Cold Spring Harbor Laboratory, NY

Sarantinopoulos P, Leroy F, Leontopoulou E. Bacteriocin production by Enterococcus faecium FAIR-E 198 in view of its application asadjunct starter in Greek Feta cheese making, Inte J Food Micr, 2002; 72: 125-136.

Tagg JR Mc, Given AR. Assay system for bacteriocins, J Appl Micr, 1971; 21: 943-947.

Verluyten V, MessensW, de Vuyst L. The curing agent sodium nitrite, used in the production of fermented sausages, is less inhibiting to the bacteriocin-producing meat starter culture Lactobacillus curvatus LTH 1174 under anaerobic conditions, Appl Env Micr, 2003; 69: 3833-3839.

Wang J, Zhang R, Zhou L, Su X, Hu C, Zhu B, Feng T. Lactobacillus inhibit adhesion of Staphylococcus aureus to HeLa cells. Sheng Wu Gong Cheng Xue Bao Chinese J Biotech, 2012; 28:715-725.

Zhang H, Cui Y, Zhu S, Feng F, Zheng X. Characterization and antimicrobial activity of a pharmaceutical microemulsion, Int J Phar, $2010 ; 395: 154-160$

\section{How to cite this article:}

Danial EN, Al-Zahrani SHM, Al-Mahmoudi ZAM. Enhancement of novel extracellular bacteriocin production by media optimization using LAB isolate from meat. J App Pharm Sci, 2016; 6 (12): 020027. 